\title{
Stimulation of $\delta$ Opioid Receptor and Blockade of Nociceptin/Orphanin FQ Receptor Synergistically Attenuate Parkinsonism
}

\author{
Omar S. Mabrouk, ${ }^{1}$ Riccardo Viaro, ${ }^{2,3}$ Mattia Volta, ${ }^{1}$ Ada Ledonne,,${ }^{4,5}$ Nicola Mercuri,,${ }^{4,5}$ and Michele Morari ${ }^{1}$ \\ ${ }^{1}$ Department of Medical Sciences, Section of Pharmacology, and National Institute of Neuroscience and ${ }^{2}$ Department of Biomedical and Specialty Surgical \\ Sciences, Section of Human Physiology, University of Ferrara, 44121 Ferrara, Italy, ${ }^{3}$ Department of Robotics, Brain, and Cognitive Sciences, Italian Institute \\ of Technology, 16163 Genoa, Italy, ${ }^{4}$ Department of System Medicine, Neurophysiopathology, University of Rome “Tor Vergata," 00133 Rome, Italy, and \\ ${ }^{5}$ Foundation S. Lucia, Institute for Inpatient Treatment and Scientific Studies, Laboratory of Experimental Neurology, 00143 Rome Italy
}

\begin{abstract}
$\delta$ opioid peptide (DOP) receptors are considered a therapeutic target in Parkinson's disease, although the use of DOP agonists may be limited by side effects, including convulsions. To circumvent this issue, we evaluated whether blockade of nociceptin/orphanin FQ (N/OFQ) tone potentiated the antiparkinsonian effects of DOP agonists, thus allowing for reduction of their dosage. Systemic administration of the N/OFQ receptor (NOP) antagonist J-113397 [(3R,4R)-1-cyclooctylmethyl-3-hydroxymethyl-4-piperidyl]-3ethyl-1,3-dihydro- $2 H$ benzimidazol-2-one] and the DOP receptor agonist SNC-80 $[(+)-4-[(\alpha R)-\alpha-(2 S, 5 R)$-allyl-2,5-dimethyl-1piperazinyl)-3-methoxy-benzyl]- $N$ - $N$-diethylbenzamide] revealed synergistic attenuation of motor deficits in 6-hydroxydopamine hemilesioned rats and 1-methyl-4-phenyl-1,2,3,6-tetrahydropyridine-treated mice. In this model, repeated administration of the combination produced reproducible antiparkinsonian effects and was not associated with rescued striatal dopamine terminals. Microdialysis studies revealed that either systemic administration or local intranigral perfusion of J-113397 and SNC-80 led to the enhancement of nigral GABA, reduction of nigral Glu, and reduction of thalamic GABA levels, consistent with the view that NOP receptor blockade and DOP receptor stimulation caused synergistic overinhibition of nigro-thalamic GABA neurons. Whole-cell recording of GABA neurons in nigral slices confirmed that NOP receptor blockade enhanced the DOP receptor-induced effect on IPSCs via presynaptic mechanisms. Finally, SNC-80 more potently stimulated stepping activity in mice lacking the NOP receptor than wild-type controls, confirming the in vivo occurrence of an NOP-DOP receptor interaction. We conclude that endogenous N/OFQ functionally opposes DOP transmission in substantia nigra reticulata and that NOP receptor antagonists might be used in combination with DOP receptor agonists to reduce their dosage while maintaining their full therapeutic efficacy.
\end{abstract}

Key words: delta opioid receptor; microdialysis; nociceptin/orphanin FQ; opioid interactions; SNC-80; substantia nigra

\section{Introduction}

$\delta$ opioid peptide (DOP) receptors are considered a therapeutic target not only in pain management but also in neuropsychiatric disorders, such as depression, anxiety, substance abuse, and Parkinson's disease (PD; Pradhan et al., 2011). In particular, DOP receptor agonists have proven to be effective analgesic, anxiolytic, antidepressant, and antiparkinsonian drugs (Chu Sin Chung and Kieffer, 2013). Unfortunately, the use of high doses of nonpeptidic DOP receptor agonists is hindered by the occurrence of adverse effects, including convulsions (Comer et al., 1993; Negus et al., 1994; Jutkiewicz et al., 2006). In addition, abuse liability

Received Nov. 5, 2013; revised June 25, 2014; accepted July 3, 2014.

Author contributions: N.M. and M.M. designed research; O.S.M., R.V., M.V., and A.L. performed research; 0.S.M. and N.M. analyzed data; M.M. wrote the paper.

This work was supported by Italian Ministry of the University PRIN 2010-2011 Grant 2010AHHP5H (M.M.). The authors declare no competing financial interests.

Correspondence should be addressed to Michele Morari, Department of Medical Sciences, Section of Pharmacology, University of Ferrara, via Fossato di Mortara 17-19, 44121 Ferrara, Italy. E-mail: m.morari@unife.it.

DOI:10.1523/JNEUROSCI.4677-13.2014

Copyright $\odot 2014$ the authors $\quad 0270-6474 / 14 / 3412953-10 \$ 15.00 / 0$ might be enhanced at high doses, and chronic treatment might induce tolerance to therapeutic effects (Jutkiewicz et al., 2005; Beaudry et al., 2009). Therefore, the development of strategies aimed at reducing the dosage of DOP agonists while maintaining their full clinical efficacy is warranted.

One of these strategies relies on the functional interactions between different opioid receptor subtypes. Indeed, classical opioid receptors, namely $\mu$ opioid peptide (MOP), $\kappa$ opioid peptide $(\mathrm{KOP})$, and DOP receptors, can be expressed in the same or different cells or tissues and positively or negatively interact at the membrane, submembrane, or circuitry level to shape the physiopharmacological responses to opioids (Smith and Lee, 2003). Subtype-selective opioid receptor ligand interactions proved effective in pain management, in which combinations of MOP and DOP, or DOP and KOP receptor agonists provide additive or synergistic analgesia (Stevenson et al., 2003, 2005; Zhang and Pan, 2010). The identification of nociceptin/orphanin FQ (N/ OFQ) and its receptor (NOP), classified as the fourth member of the opioid receptor family, has widened the spectrum of potential therapeutic combinations. Indeed, endogenous N/OFQ has been 
Table 1. Baseline activity of animals used in the study

\begin{tabular}{|c|c|c|c|}
\hline & $\begin{array}{l}\text { Bar test (immobility } \\
\text { time in seconds) }\end{array}$ & $\begin{array}{l}\text { Drag test (number } \\
\text { of steps) }\end{array}$ & $\begin{array}{l}\text { Rotarod test (time on } \\
\text { rod in seconds) }\end{array}$ \\
\hline $6-0$ HDA rats $(n=32)$ & & & $479 \pm 31^{* *}$ \\
\hline Ipsilateral & $16.8 \pm 1.7$ & $11.4 \pm 0.2$ & \\
\hline Contralateral & $30.8 \pm 2.6^{*}$ & $2.5 \pm 0.2^{*}$ & \\
\hline Naive rats ${ }^{a}$ & $1.2 \pm 0.1$ & $11.8 \pm 0.2$ & $1138 \pm 61$ \\
\hline MPTP-treated mice $(n=27)$ & $11.6 \pm 2.1^{* *}$ & $11.1 \pm 0.3^{* *}$ & $589 \pm 25^{* *}$ \\
\hline Naive mice $(n=8)$ & $0.5 \pm 0.1$ & $14.1 \pm 0.5$ & $850 \pm 22$ \\
\hline Naive $\mathrm{NOP}^{+/+}$mice $(n=14)$ & nt & $13.9 \pm 0.6$ & nt \\
\hline Naive $N O P^{-1-}$ mice $(n=12)$ & $\mathrm{nt}$ & $17.1 \pm 0.6^{* *}$ & nt \\
\hline
\end{tabular}

The number of animals used to generate the data is indicated in parentheses. Data have been analysed using the Student's $t$ test for unpaired data. ${ }^{*} p<0.01$, different from the ipsilateral side; ${ }^{* *} p<0.01$, different from naive control animals. nt, Not tested.

${ }^{a}$ Taken from Marti et al. (2008).

demonstrated to physiologically oppose MOP agonist-induced analgesia at the supraspinal level and to potentiate it at the spinal level (Tian et al., 1997; Hu et al., 2010). Consistently, systemic administration of NOP receptor antagonists potentiated buprenorphine-induced analgesia (Lutfy et al., 2003), whereas intrathecal injections of N/OFQ with morphine caused synergistic analgesia (Ko and Naughton, 2009). This indicates that, depending on the localization of the NOP receptor, N/OFQ can powerfully and bidirectionally regulate the processing of nociceptive information mediated by MOP receptors. However, outside pain management the interaction between N/OFQ and classical opioid receptors and its therapeutic potential have not been explored.

In the present study, we investigated the role of endogenous N/OFQ in the modulation of the behavioral and neurochemical responses to a DOP agonist, SNC-80 $[(+)-4-[(\alpha R)-\alpha-(2 S, 5 R)$-allyl-2,5dimethyl-1-piperazinyl)-3-methoxy-benzyl]-N-N-diethylbenzamide], in the 6-hydroxydopamine (6-OHDA) hemilesioned rat and 1-methyl4-phenyl 1,2,3,6 tetrahydropyridine (MPTP)-treated mouse models of PD.

\section{Materials and Methods}

The experimental protocols performed in the present study were approved by the Ethical Committee of the University of Ferrara and the Italian Ministry of University (licenses 94-2007-B and 194-2008-B). Adequate measures were taken to minimize animal pain and discomfort and to limit the number of animals used.

\section{Studies in rats (Experiments 1 and 4-6)}

Unilateral lesion with 6-OHDA. Unilateral lesions of substantia nigra (SN) compacta dopamine (DA) neurons were made by stereotaxic injection of $8 \mu \mathrm{g}$ of 6-OHDA into the right medial forebrain bundle of isoflurane-anesthetized male Sprague Dawley rats (150 g; Harlan), as described previously (Marti et al., 2005, 2007). Two weeks after surgery, rats showing more than seven ipsilateral turns per minute in response to a testing dose of amphetamine $(5 \mathrm{mg} / \mathrm{kg}$, i.p.) were enrolled in the study, because this behavior is associated with $>95 \%$ loss of striatal DA terminals (Marti et al., 2007) and extracellular DA levels (Marti et al., 2002). Experiments were performed $6-8$ weeks after surgery.

Behavioral studies. Thirty-two 6-OHDA hemilesioned rats were allotted in four groups receiving the following: (1) vehicle; (2) J-113397 (1-[(3R,4R)-1-cyclooctylmethyl-3-hydroxymethyl-4-piperidyl]-3ethyl-1,3-dihydro-2 $H$ benzimidazol-2-one; $0.1 \mathrm{mg} / \mathrm{kg}$ ); (3) SNC-80 (0.1 $\mathrm{mg} / \mathrm{kg}$ ); and (4) their combination. Three behavioral tests, complementary for different motor functions (the bar, drag, and rotarod tests) were performed before (control) and then 20 and 70 min after drug injection (Marti et al., 2005, 2007). The bar test (Kuschinsky and Hornykiewicz, 1972) measures the ability of the rat to respond to an imposed static posture. Rat forepaws were placed alternatively on blocks of increasing heights $(3,6$, and $9 \mathrm{~cm})$, and total time (in seconds) spent by each paw on the blocks was recorded (cutoff time, $20 \mathrm{~s}$ ). The drag test (modification of the "wheelbarrow test"; Schallert et al., 1979) measures the ability of the rat to balance body posture using the forelimbs in response to backward dragging. Rats were lifted from the tail (allowing the forepaws to rest on the table) and dragged backward at a constant speed $(\sim 20 \mathrm{~cm} / \mathrm{s})$ for a fixed distance $(100 \mathrm{~cm})$. The number of steps made by each forepaw was counted by two separate observers. The fixed-speed rotarod test (Rozas et al., 1997) measures overall motor performance as an integration of coordination, gait, balance, muscle tone, and motivation to run. Initially, rats were trained for $10 \mathrm{~d}$ to a complete motor task on the rotarod (i.e., from 5 to $55 \mathrm{rpm} ; 180 \mathrm{~s}$ each) until their motor performance became reproducible in three consecutive sessions. Rats were then tested at four increasing speeds (usually 10, 15, 20, and $25 \mathrm{rpm}$ ), causing a progressive decrement of performance to $\sim 40 \%$ of the maximal response (i.e., the experimental cutoff time; Marti et al., 2004).

Microdialysis and analysis of endogenous Glu and GABA. Two concentric probes ( $1 \mathrm{~mm}$ dialyzing membrane, AN69; Hospal) were stereotaxically implanted, under isoflurane anesthesia, in the lesioned SN reticulata (SNr) and ipsilateral globus pallidus (GP) or ventromedial thalamus (VMTh; coordinates from bregma (in $\mathrm{mm}$ ): $\mathrm{SNr}, \mathrm{AP}-5.5, \mathrm{ML}-2.2, \mathrm{DV}$ -8.3; GP, AP - 1.3, ML - 3.3, DV - 6.5; VMTh, AP - 2.3, ML - 1.4, DV -7.4; Paxinos and Watson, 1986). Twenty-four hours after probe implantation, microdialysis probes were perfused $(3.0 \mu \mathrm{l} / \mathrm{min})$ with a modified Ringer's solution, and samples were collected every $15 \mathrm{~min}$ (Marti et al., 2005, 2007). Experiments were run at 24, 48, and $72 \mathrm{~h}$ after implantation, and treatments were randomized. Glu and GABA were measured by HPLC coupled with fluorometric detection after precolumn derivatization with $o$-phthaldialdehyde/mercaptoethanol reagent (Marti et al., 2007).

Electrophysiology. Whole-cell patch-clamp recordings of GABA neurons of SNr were performed on acutely extracted brain slices of Wistar rats (17-23 d old; Berretta et al., 2000). Electrophysiological recordings of spontaneous and evoked GABAergic transmission were performed with glass borosilicate pipettes filled with a solution containing the following (in mM): $145 \mathrm{KCl}, 0.05 \mathrm{CaCl}_{2}, 0.1$ EGTA, $10 \mathrm{HEPES}, 0.3 \mathrm{Na}_{3}$-GTP, and $4 \mathrm{Mg}$-ATP 4, pH 7.35. To study evoked GABA transmission, the $\mathrm{Na}^{+}$ channel blocker QX-314 [2(triethylamino)- $N$-(2,6-dimethylphenyl) acetamine] was added ( $5 \mathrm{~mm}$ ) to the internal solution. Neurons were held at $-70 \mathrm{mV}$. Current signals were filtered at $3 \mathrm{kHz}$ and digitized at $10 \mathrm{kHz}$ using a Multiclamp 700A (Molecular Devices) operated by the

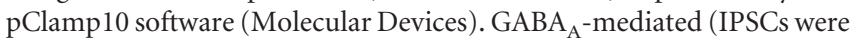
pharmacologically isolated using a mixture containing CNQX $(10 \mu \mathrm{M})$, MK-801 (10 $\mu \mathrm{M})$, and CGP55845 (2S)-3-[(1S)-1-(3,4-dichlorophenyl)ethyl]amino-2-hydroxypropyl)(phenylmethyl)phosphinic acid; $1 \mu \mathrm{M}$ ] to block glutamatergic (AMPA, NMDA) and $\mathrm{GABA}_{\mathrm{B}}$ receptors, respectively.

Spontaneous IPSCs (sIPSCs) were analyzed from 3 min trace recordings with Clampfit (Molecular Devices). Evoked IPSCs (eIPSCs) were elicited with a monopolar electrode placed in $\mathrm{SNr}$ by applying a single stimulus pulse $(60-100 \mu \mathrm{s}, 20-100 \mu \mathrm{A})$ delivered every $20 \mathrm{~s}$. In some experiments, two stimuli at $50 \mathrm{~ms}$ were applied, and the paired-pulse ratio (PPR) between the IPSC2 and IPSC1 amplitudes was calculated.

\section{Studies in mice (Experiments 2, 3, and 7)}

Male C57BL/6J mice (20-25 g; Harlan) were acutely injected with MPTP $(4 \times 20 \mathrm{mg} / \mathrm{kg}$, i.p., $90 \mathrm{~min}$ apart). Drug effect was evaluated at $7 \mathrm{~d}$ after intoxication, i.e., when degeneration of DA neurons and motor impairment attained stable levels (Viaro et al., 2010). Twenty-seven mice were allotted into five treatment groups receiving the following: (1) saline ( $n=$ 6); (2) $0.001 \mathrm{mg} / \mathrm{kg} \mathrm{J-113397} \mathrm{(} n=5)$; (3) $0.01 \mathrm{mg} / \mathrm{kg} \mathrm{SNC-80}(n=5)$; (4) $0.1 \mathrm{mg} / \mathrm{kg} \mathrm{SNC}-80(n=5)$; or (5) J-113397 plus $0.01 \mathrm{mg} / \mathrm{kg} \mathrm{SNC}-80(n=$ 6). Motor activity was assessed similar to rats (described above), with the only difference being the block heights in the bar test $(1.5,3$, and $6 \mathrm{~cm})$.

In a second set of experiments, the subacute drug effect was evaluated. Mice were treated with MPTP as above and allotted into 4 treatment groups: (1) saline; (2) $0.01 \mathrm{mg} / \mathrm{kg} \mathrm{SNC-80;} \mathrm{(3)} 0.001 \mathrm{mg} / \mathrm{kg} \mathrm{J-113397;} \mathrm{and}$ (4) $0.01 \mathrm{mg} / \mathrm{kg}$ SNC-80 plus $0.001 \mathrm{mg} / \mathrm{kg} \mathrm{J-113397.} \mathrm{Drugs} \mathrm{were} \mathrm{coadmin-}$ istered twice daily (8:00 A.M. and 8:00 P.M.) for $7 \mathrm{~d}$, starting from $60 \mathrm{~min}$ after the last MPTP injection. Motor tests were performed 2, 4, and $6 \mathrm{~d}$ after MPTP ( $6 \mathrm{~h}$ after the first daily drug treatment). At the end of treatments, tyrosine hydroxylase $(\mathrm{TH})$ immunohistochemistry was performed on striatal slices. 

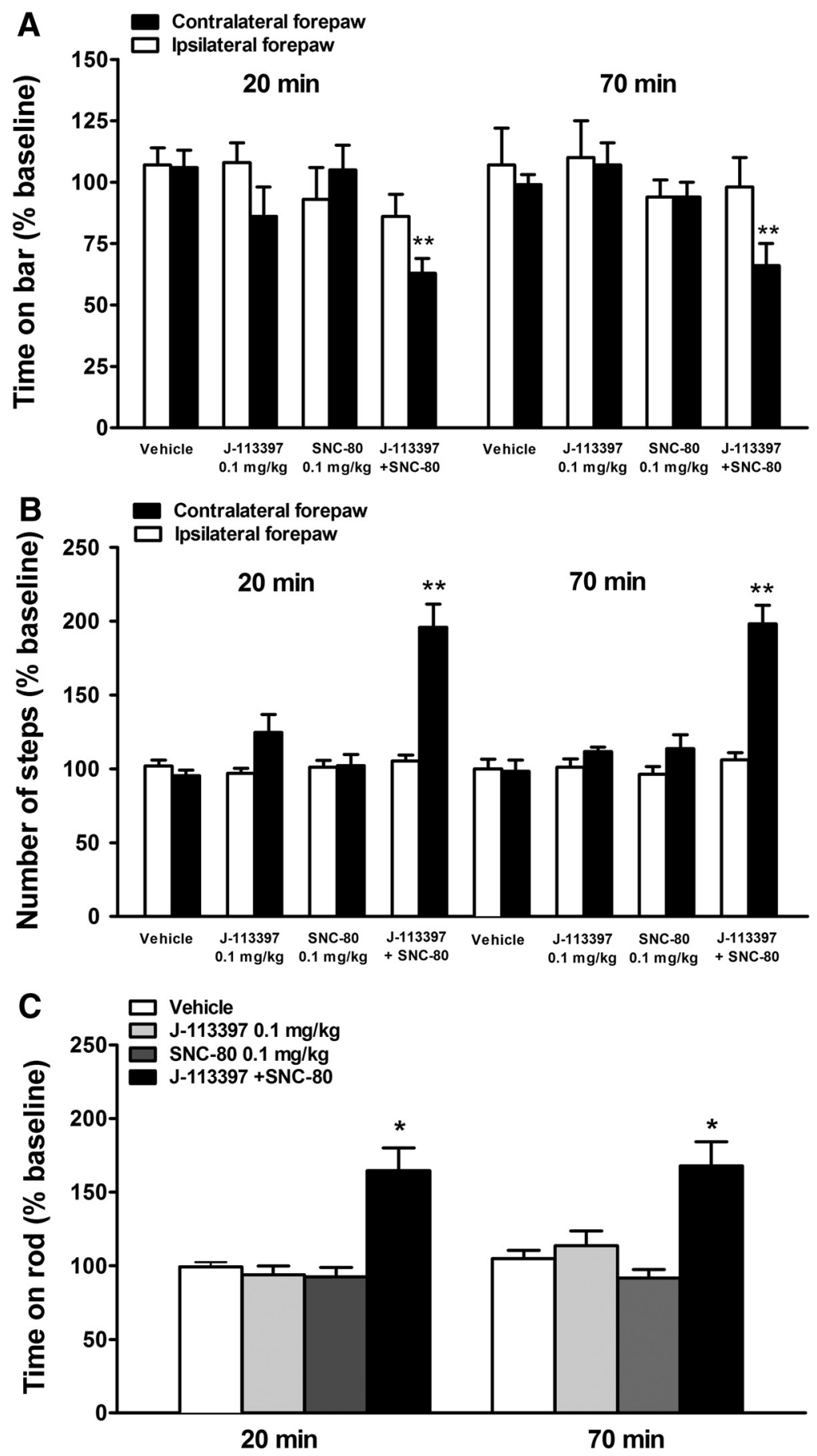

Figure 1. Coadministration of the NOP antagonist J-113397 and the DOP agonist SNC-80 attenuates parkinsonism in 6-OHDA hemilesioned rats. J-113397 and SNC-80 were administered intraperitoneally at low subthreshold ( $0.1 \mathrm{mg} / \mathrm{kg}$ both) doses, and motor activity was evaluated in the bar $(\boldsymbol{A}), \operatorname{drag}(\boldsymbol{B})$, and rotarod $(\boldsymbol{C})$ tests. In the bar and drag tests, motor activity was measured at the ipsilateral and contralateral paws. Each experiment consisted of three different sessions: a control session, followed by two other sessions performed 20 and 70 min after saline or drug administration. Data are expressed as percentages of motor performance in the control session and are means \pm SEMs of eight rats per group. Statistical analysis was performed by RM-ANOVA, followed the sequentially rejective Bonferroni's test. ${ }^{*} p<0.05,{ }^{* *} p<0.01$, different from vehicle.

with PBS, and fixed with cold $4 \%$ paraformaldehyde (Viaro et al., 2010). Brains were removed, postfixed overnight, and transferred to $20 \%$ sucrose. Five coronal sections $(40 \mu \mathrm{m}$ thickness) were cut at different levels of the striatum and incubated with anti-TH mouse monoclonal antibody and biotinylated horse anti-mouse IgG secondary antibody. Immunoreactivity was visualized using avidin-biotin-peroxidase complex and 3,3-diaminobenzidine in $\mathrm{H}_{2} \mathrm{O}_{2}$. TH-immunoreactive fiber density was calculated using NIH ImageJ software (Wayne Rasband, National Institutes of Health, Bethesda, $\mathrm{MD})$. Optical density was corrected for nonspecific background, measured in the corpus callosum.

\section{Statistical analysis}

Behavioral and neurochemical data were analyzed by one-way repeated-measures (RM) ANOVA, followed by the sequentially rejective Bonferroni's test. Drug effects on sIPSCs were evaluated as changes in their amplitude or interevent interval (IEI) using the Kolmogoro$\mathrm{v}-\mathrm{Smirnov}$ test on their mean cumulative distributions or by comparing mean median values with the Student's $t$ test. Drug effect on eIPSCs was expressed as normalized mean of peak amplitudes and statistically compared using the Student's $t$ test. $p$ values $<0.05$ were considered to be statistically significant.

\section{Materials}

D-Amphetamine sulfate, MPTP hydrochloride, and 6-OHDA hydrobromide were purchased from Sigma, and SNC-80 was from Tocris Bioscience. J-113397 and UFP-101 ([Nphe ${ }^{1}$, Arg $^{14}{ }^{14}$ Lys $^{15}{ }^{15}$ N/OFQ-NH2) were a generous gift from Prof. S. Salvadori (University of Ferrara, Ferrara, Italy). $\mathrm{NOP}^{+/+}$and $N O P^{-/-}$mice were donated by Prof. G. Calò (University of Ferrara). SNC-80 was dissolved in $0.5 \%$ DMSO and then diluted in saline (intraperitoneal injection) or Ringer's solution (reverse dialysis).

\section{Results}

Experiment 1: effects of systemic administration of J-113397 and SNC-80 on motor behavior in 6-OHDA hemilesioned rats

To prove whether endogenous N/OFQ could affect the antiparkinsonian response to a DOP agonist, the small-molecule NOP receptor antagonist J-113397 was systemically coadministered with the smallmolecule DOP agonist SNC-80 in 6-OHDA hemilesioned rats. The low $0.1 \mathrm{mg} / \mathrm{kg}$ dose of J-113397 was chosen because this dose caused mild reduction of immobility time, no change in stepping activity, and inconsis-

In a third series of experiments, male homozygous CD1/C57BL/6J/129 $N_{O P}^{+/+}(n=14)$ and $N O P^{-/-}$mice $(n=12 ; 8-10$ weeks old; $20-25 \mathrm{~g}$; Ferrara vivarium; Nishi et al., 1997) were assigned to different doses of SNC-80 (0.01-3 mg/kg). Each mouse was administered two or three times (every $4 \mathrm{~d}$ ), with different doses, in a randomized manner.

For TH immunohistochemistry, animals were deeply anesthetized (85 $\mathrm{mg} / \mathrm{kg}$ ketamine plus $15 \mathrm{mg} / \mathrm{kg}$ xylazine, i.p.), transcardially perfused tent effects on rotarod performance in previous studies (Marti et al., 2005, 2007). We reasoned that this overall "threshold" response, suggestive of a mild blockade of the NOP receptor in vivo, could set an ideal background for unraveling a synergistic interaction with a subthreshold dose of SNC-80 (0.1 mg/kg; Mabrouk et al., 2008). Hemilesioned rats showed motor asymmetry, with the contralateral 

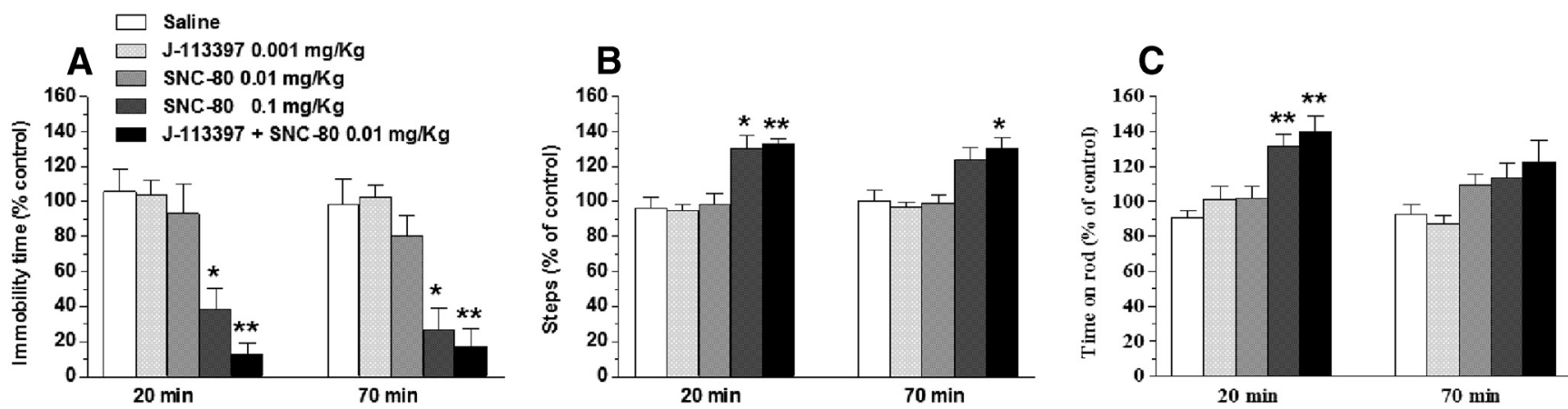

Figure 2. Combined administration of subthreshold doses of J-113397 and SNC-80 caused synergistic attenuation of parkinsonism in MPTP-treated mice. Mice were acutely injected with MPTP $(4 \times 20 \mathrm{mg} / \mathrm{kg}$, i.p., $90 \mathrm{~min}$ apart), and J-113397 $(0.001 \mathrm{mg} / \mathrm{kg})$ and SNC-80 (0.01 and $0.1 \mathrm{mg} / \mathrm{Kg})$ were administered alone or in combination (intraperitoneally) $7 \mathrm{~d}$ afterward. Motor activity was evaluated in the bar $(\boldsymbol{A})$, drag $(\boldsymbol{B})$, and rotarod $(\boldsymbol{C})$ tests. Each experiment consisted of three different sessions: a control session, followed by two other sessions performed 20 and 70 min after saline or drug administration. Data are expressed as percentage means \pm SEMs of control session of five to six mice per group. Statistical analysis was performed by one-way RM-ANOVA, followed by the sequentially rejective Bonferroni's test. ${ }^{*} p<0.05,{ }^{* *} p<0.01$, different from vehicle.
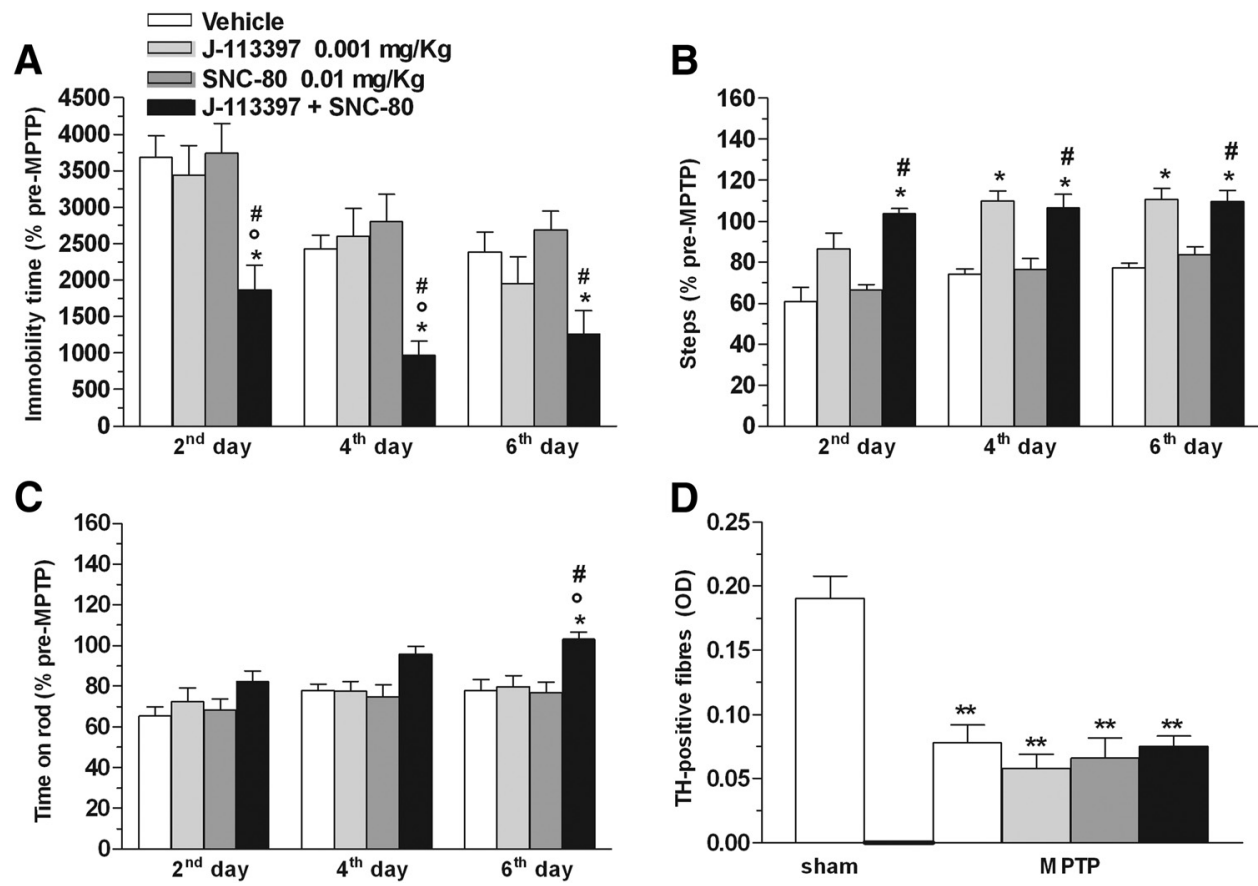

Figure 3. Subacute administration of subthreshold doses of J-113397 and SNC-80 caused symptomatic relief that was not associated with sparing of striatal DA terminals. Mice were injected with MPTP ( $4 \times 20 \mathrm{mg} / \mathrm{kg}$, i.p., $90 \mathrm{~min}$ apart) and allotted in four treatment groups: (1) saline; (2) $0.01 \mathrm{mg} / \mathrm{kg} \mathrm{SNC-80;} \mathrm{(3)} 0.001 \mathrm{mg} / \mathrm{kg} \mathrm{J-113397;} \mathrm{and} \mathrm{(4)} \mathrm{their} \mathrm{combination.} \mathrm{Drugs} \mathrm{were} \mathrm{administered}$ twice daily (8:00 A.M. and 8:00 P.M.) starting $60 \mathrm{~min}$ after the last MPTP injection. Motor activity was evaluated in the bar $(\boldsymbol{A})$, drag $(\boldsymbol{B})$, and rotarod $(\boldsymbol{C})$ tests, performed $(6 \mathrm{~h}$ after the first daily treatment) at 2, 4, and $6 \mathrm{~d}$ after MPTP intoxication. TH immunohistochemistry was performed at the end of treatment (D). Data are expressed as percentage means \pm SEMs of pre-MPTP values of six to seven mice per group. Statistical analysis was performed by one-way RM-ANOVA, followed by the sequentially rejective Bonferroni's test (A-C) or one-way ANOVA, followed by the Newman-Keuls test $(\boldsymbol{D}) .{ }^{*} p<0.05,{ }^{* *} p<0.01$, different from vehicle $(\boldsymbol{A}-\boldsymbol{C})$ or sham (D). ${ }^{\circ} p<0.05$, different from J-113397 alone. ${ }^{\#} p<0.05$, different from SNC-80 alone.

(parkinsonian) paw being more akinetic and bradykinetic than the ipsilateral paw, and an impairment of rotarod performance (Table 1).

Low doses of either drug $(0.1 \mathrm{mg} / \mathrm{kg})$ were ineffective alone in each test but produced marked and prolonged (up to $70 \mathrm{~min}$ ) reductions of immobility time (37\%; Fig. $1 A$ ), as well as increases of stepping activity at the contralateral paw (98\%; Fig. $1 B$ ) and rotarod performance (65\%; Fig. $1 C$ ) when administered in combination.

Experiment 2: effect of acute administration of J-113397 and SNC-80 on motor behavior in MPTP-treated mice

To confirm that the synergism between an NOP antagonist with a DOP agonist was not species and model dependent, J-113397 and SNC-80 were administered to MPTP-treated mice at $7 \mathrm{~d}$ after intoxication. MPTP-treated mice showed increased immobility time in the bar test $(11.6 \pm 2.1 \mathrm{~s})$, reduced stepping activity in the drag test ( $11.1 \pm 0.3$ steps $)$, and impaired rotarod performance $(589.2 \pm 25 \mathrm{~s})$ compared with saline-injected mice $(0.5 \pm 0.1 \mathrm{~s}, 14.1 \pm 0.5$ steps, and $850.8 \pm$ $22.0 \mathrm{~s}$, respectively; $p<0.0001)$. SNC-80 was ineffective at $0.01 \mathrm{mg} / \mathrm{kg}$ but caused reduction of immobility time (Fig. 2A) and an increase in stepping activity (Fig. $2 B$ ) and rotarod performance (Fig. $2 C$ ) at $0.1 \mathrm{mg} / \mathrm{Kg}$. The combination of an ineffective, subthreshold dose of J-113397 (0.001 mg/kg; Viaro et al., 2008, 2010) with SNC-80 (0.01 mg/kg) caused significant attenuation of akinesia that was quantitatively similar to that produced by the higher SNC-80 dose alone. 

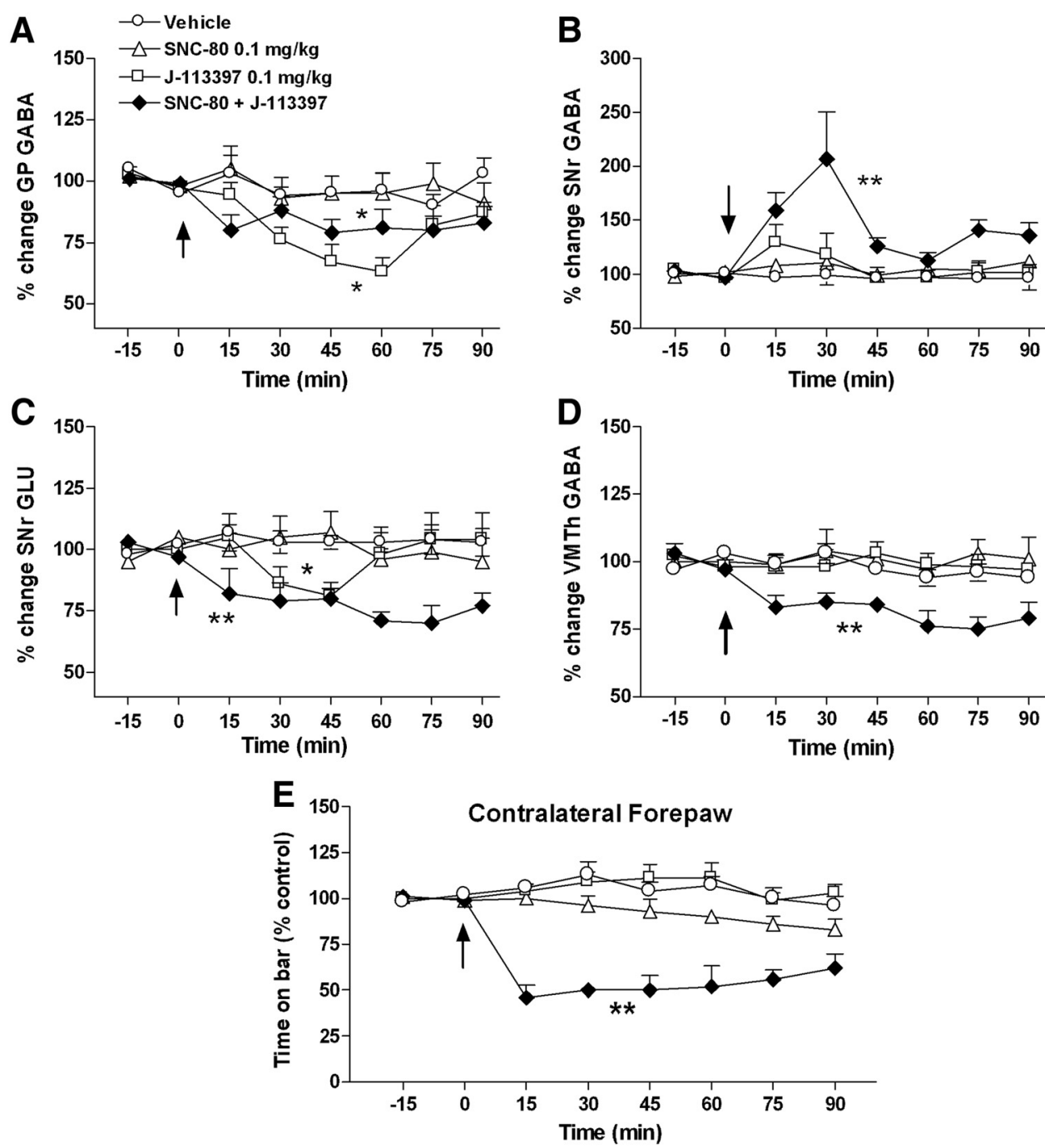

Figure 4. Combined administration of subthreshold doses of J-113397 and SNC-80 alleviated akinesia and modulated GABA and Glu levels in the basal ganglia and thalamus. Two microdialysis probes were implanted in the lesioned SNr and ipsilateral GP or VMTh of hemiparkinsonian rats and GABA and/or Glu levels monitored in GP $(\boldsymbol{A})$, SNr $(\boldsymbol{B}, \boldsymbol{C})$, and VMTh (D) simultaneously with immobility time at the contralateral paw (bar test; E). J-113397 and SNC-80 were administered alone and in combination $(0.1 \mathrm{mg} / \mathrm{kg}$ each, i.p.; arrow). Data are expressed as percentage means \pm SEMs of pretreatment (basal) values of seven determinations per group. Basal amino acid levels in the dialysate were as follows (in nM): GP (GABA, 2.9 \pm 0.3 ), SNr (GABA, 3.1 $\pm 0.4 ; \mathrm{Glu}, 72.5 \pm$ 7.5), and VMTh (GABA, $4.1 \pm 0.4)$. Statistical analysis was performed by one-way RM-ANOVA, followed by the sequentially rejective Bonferroni's test. ${ }^{*} p<0.05{ }^{* *} p<0.01$, different from vehicle.

Experiment 3: effect of repeated administration of J-113397 and SNC-80 on motor activity and striatal DA terminal density in MPTP-treated mice

We then tested whether repeated administration of the combination of subthreshold doses of J-113397 and SNC-80 could provide prolonged symptomatic relief and protect DA terminals from MPTP-induced degeneration. J-113397 (0.001 mg/kg) and SNC-80 $(0.01 \mathrm{mg} / \mathrm{kg})$ were ineffective alone but provided longlasting reduction of immobility time in combination (Fig. $3 A$ ). In the drag test, J-113397 alone improved stepping activity, starting from day 4 of administration, whereas SNC-80 alone was ineffective (Fig. 3B). The combination of the two caused a more rapid normalization of stepping beginning at the first challenge (Fig. $3 B)$. Finally, neither drug alone improved rotarod performance (Fig. 3C), whereas the combination caused normalization of rotarod performance at the end of treatment (day 6).

Striatal TH immunohistochemistry did not reveal any sparing of striatal DA terminals after each drug alone or in combination (Fig. 3C).
Experiment 4: effects of systemic administration of J-113397 and SNC-80 on pallidal and nigral neurotransmitter release Dual-probe microdialysis was used to investigate the circuitry underlying the synergistic interaction between low doses $(0.1 \mathrm{mg} /$ $\mathrm{kg}$ ) of J-113397 and SNC-80. By monitoring GABA and Glu levels, we first evaluated whether drug synergism reverberated in GP or SNr transmission. J-113397 caused a robust (37\%) reduction of GABA levels in GP, whereas SNC-80 was ineffective alone and did not change the effect of J-113397 (Fig. 4A). Pallidal Glu levels were not affected by any treatment (data not shown). Different from GP, each compound individually was ineffective on amino acid levels in $\mathrm{SNr}$, whereas the combination evoked a robust increase in GABA (107\%) and a sustained decrease (30\%) in Glu (Fig. $4 B, C$ ).

To investigate whether the synergistic interaction involved changes along the nigro-thalamic pathway (the nigral output), GABA levels in VMTh were monitored. Either drug given alone did not affect VMTh GABA levels, whereas their combination caused a sustained decrease (25\%; Fig. 4D). 

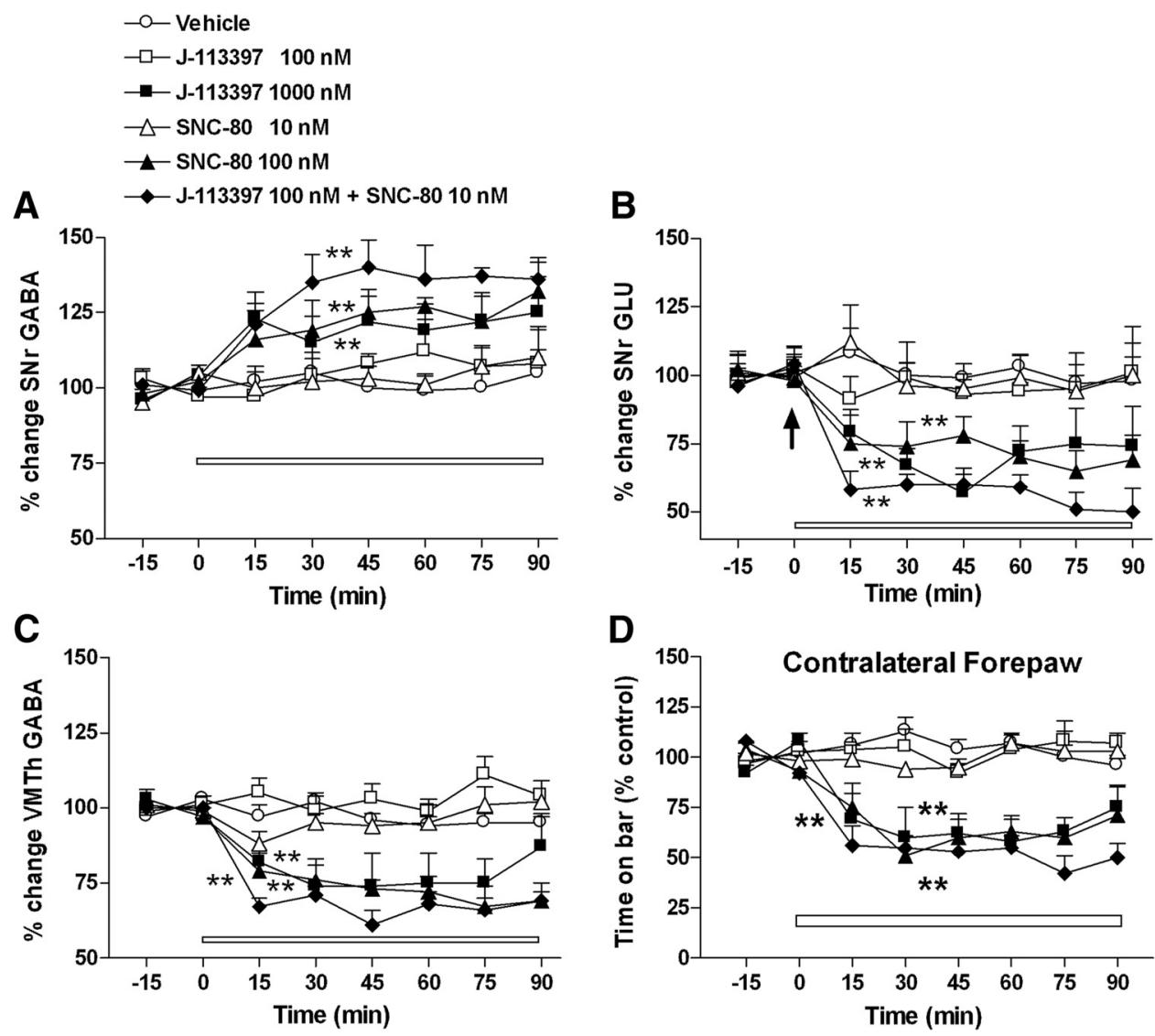

Figure 5. Reverse dialysis of J-113397 and SNC-80 in SNr alleviated akinesia and modulated GABA and Glu levels in SNr and ipsilateral VMTh. Two microdialysis probes were implanted in the lesioned SNr and ipsilateral VMTh of hemiparkinsonian rats, and GABA and/or Glu levels were monitored in $\mathrm{SNr}(\boldsymbol{A}, \boldsymbol{B})$ and VMTh $(\boldsymbol{C})$ simultaneously with immobility time at the contralateral paw (bar test; D).J-113397 (100 nм and $1 \mu \mathrm{M}$ ) and SNC-80 (10 and $100 \mathrm{~nm}$ ) were locally perfused in SNr, alone or in combination (at the lower concentrations only). Data are expressed as percentage means \pm SEMs of pretreatment (basal) values of seven determinations per group. Basal amino acid levels in the dialysate were as follows (in nM): SNr (GABA, 4.2 $\pm 0.3 ;$ Glu, 139.9 \pm 14.3 ) and VMTh (GABA, $5.6 \pm 0.3)$. Statistical analysis was performed by one-way RM-ANOVA, followed by the sequentially rejective Bonferroni's test. ${ }^{* *} p<0.01$, different from vehicle.

The bar test performed simultaneously with sample collection confirmed that the combination of J-113397 and SNC-80 caused long-lasting relief from akinesia at the contralateral paw, whereas each drug given individually had no effect (Fig. $4 E$ ).

Experiment 5: reverse dialysis of J-113397 and SNC-80 in SNr on nigral and thalamic neurotransmitter release

To investigate whether the interaction between NOP and DOP receptor ligands was taking place in $\mathrm{SNr}$, compounds were administered by reverse dialysis. Local perfusion of J-113397 (100 nM) and SNC-80 (10 nM) in SNr had no effect on nigral GABA (Fig. 5A) and Glu (Fig. 5B), whereas higher concentrations of both compounds ( $1 \mu \mathrm{M}$ and $100 \mathrm{nM}$, respectively) increased GABA (32 and 25\%, respectively) and reduced Glu (35 and 43\%, respectively). The combination of ineffective concentrations of J-113397 and SNC-80 evoked an increase in extracellular GABA and a reduction in Glu levels that was superimposable to that induced by the higher concentrations perfused alone (Fig. $5 A, B$ ).

To investigate whether the synergistic neurochemical responses could be associated with a synergistic inhibition of the nigral output, GABA release was monitored in ipsilateral VMTh (Fig. 5C). Nigral perfusion of J-113397 (100 nM) and SNC-80 (10 nM) alone failed to affect thalamic GABA, whereas perfusion of the higher concentrations reduced it (38 and 26\%, respectively). Combination of ineffective concentrations of both compounds resulted in a significant reduction of GABA that was similar to that produced by each of the higher concentrations alone.
Consistent with neurochemical data, low concentrations of J-113397 and SNC-80 were ineffective alone but attenuated akinesia when given in combination (Fig. 5D).

\section{Experiment 6: electrophysiological effects of SNC-80 and UFP-101 in slices of rat $\mathrm{SNr}$}

To prove that the cooperative interaction between NOP antagonist and DOP agonist was attributable to enhanced GABA release, causing overinhibition of nigral output neurons, we performed electrophysiological recordings of the GABAergic synaptic transmission targeting SNr GABA neurons. For these in vitro studies, we used a peptidic NOP receptor antagonist, UFP-101, that binds to the NOP receptor with greater affinity and selectivity over classical opioid receptors than J-113397 (Calo et al., 2005). Bath application of UFP-101 (100 nM) or SNC-80 (10 nM) alone did not affect spontaneous $\mathrm{GABA}_{\mathrm{A}}$-mediated synaptic transmission (Fig. 6). However, when SNC-80 was applied after UFP-101, a significant increase of sIPSCs amplitude with a right shift of the cumulative distribution curve (Fig. 6) was observed. This was associated with a significant reduction of sIPSC IEIs, causing a leftward shift of the IEI cumulative distribution curve.

The effect on the evoked $\mathrm{GABA}_{\mathrm{A}}$-mediated synaptic transmission was then studied. UFP-101 (100 nM) and SNC-80 (10 nM) potentiated the electrically evoked GABAergic synaptic transmission (47 and 87\%, respectively). However, when SNC-80 was applied after UFP-101, an effect that was more than additive was recorded, with eIPSC peak amplitude increasing to $336 \%$ of con- 
A

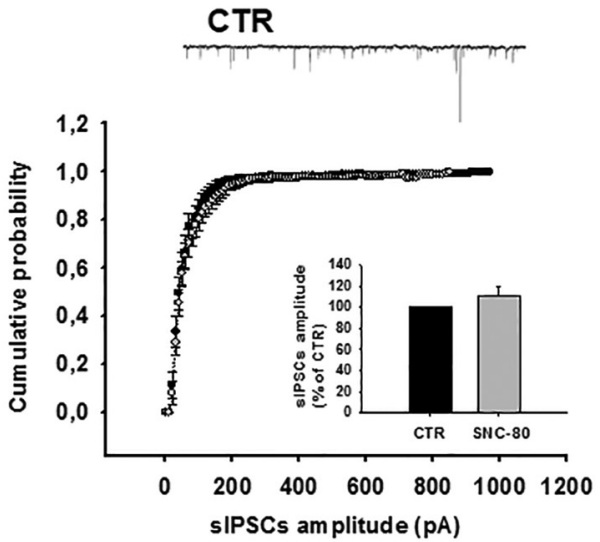

SNC-80

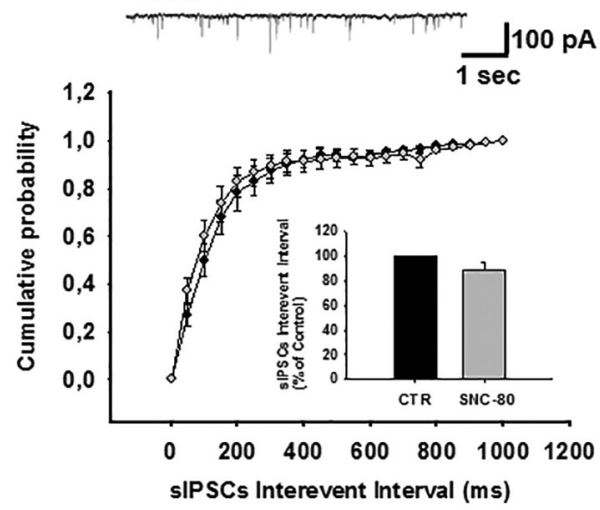

B CTR

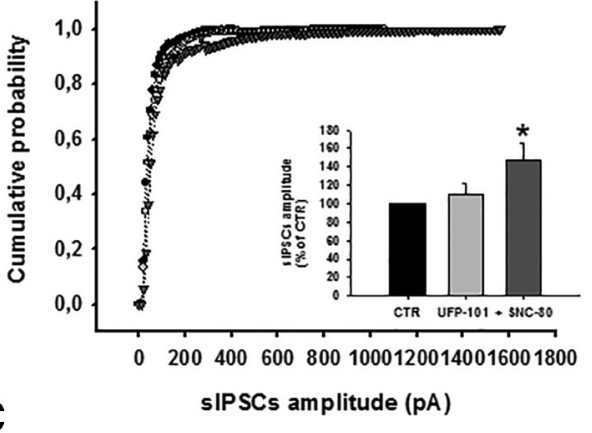

UFP-101

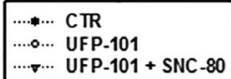

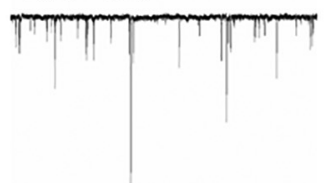

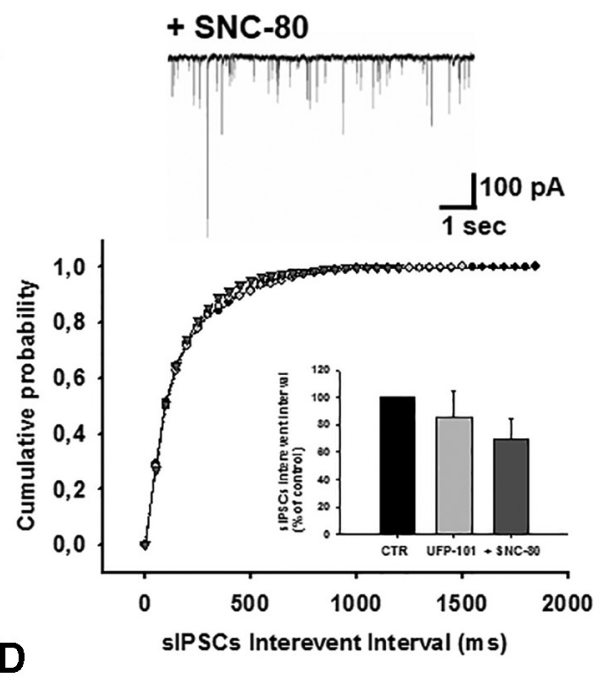

D

CTR UFP-101 + SNC-80

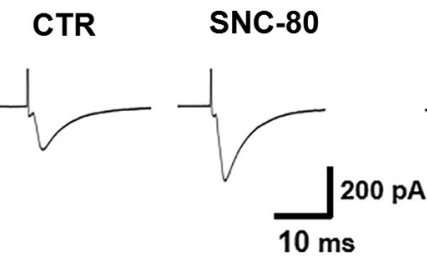
CTR UFP-101 UFP-101 + $\overbrace{\left.\right|_{10 \mathrm{~ms}} ^{200 \mathrm{pA}}}$
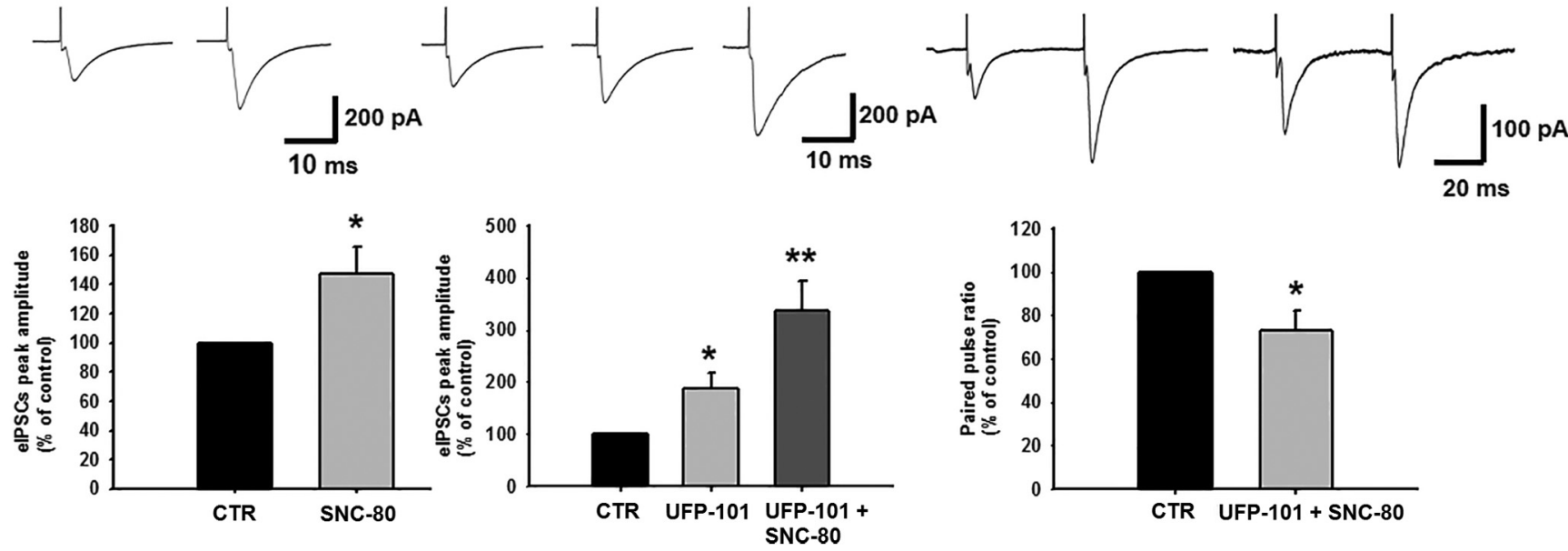

Figure 6. Synergistic effect of SNC-80 and UFP-101 on spontaneous and evoked GABAergic synaptic transmission targeting SNr GABA neurons. $A$, SNC-80 (10 nM) did not produce a significant modulation of sIPSCS in SNr GABAergic neurons as shown in representative traces (top) in an amplitude (left) and IEI (right) cumulative distribution of sIPSCS (7 cells). SNC-80 did not modify sIPSC amplitude distribution and interevent distribution. Insets, Group analysis histograms (normalized medians \pm SEMs) of sIPSC amplitude (left) and IEI (right) of a total of seven neurons. $\boldsymbol{B}$, UFP-101 $(100 \mathrm{nM}$ ) alone did not induce a significant modulation of sIPSCS. However, consequent application of SNC-80 (10 nM) produced an enhancement of spontaneous GABAergic transmission, as shown in representative traces (top) and in amplitude (left) and IEI (right) cumulative distribution of SIPSCS (7 cells). Concomitant application of UFP-101 and SNC-80 increased sIPSC amplitude distribution and reduced sIPSC interevent distribution. Insets, Group analysis histograms (normalized medians \pm SEMs) of sIPSC amplitude (left) and IEl (right). C, SNC-80 and UFP-101 produced a synergistic modulation of stimulus-evoked GABAergic transmission. Left, SNC-80 (10 nM) significantly increased elPSCs as shown in representative traces (top) and histogram of normalized elPSC peak amplitude. Right, UFP-101 (100 nM) also induced a significant enhancement of elPSCs that is strongly augmented by the concomitant application of SNC-80 (10 nM) as shown in representative traces (top) and histogram of normalized elPSCs peak amplitude $(n=7)$. D, Effect of concomitant application of UFP-101 and SNC-80 on synaptic facilitation of elPSCs induced by application of a paired pulse (PP) stimulation protocol. Ratio between second and first elPSCS (PPR) was reduced in the presence of UFP-101 (100 nM) plus SNC-80 (10 nM) as shown in representative traces and in the histogram of normalized PPR. ${ }^{*} p<0.05,{ }^{* *} p<0.01$, different from control (CTR). 
trol. This effect was associated with a significant $27 \%$ reduction of $\mathrm{PPR}$, indicating that the increase in eIPSPs was attributable to increased neurotransmitter release from GABA terminals.

\section{Experiment 7: effect of $\mathrm{SNC}-80$ in naive $\mathrm{NOP}^{+/+}$and $\mathrm{NOP}^{-/-}$mice}

To corroborate the data supporting an NOP-DOP receptor interaction in nigral slices and also confirm that blockade of NOP receptors potentiates DOP responses in naive animals in vivo, SNC-80 was tested in mice carrying genetic deletion of the NOP receptor $\left(\mathrm{NOP}^{-/-}\right)$compared with wild-type controls $\left(\mathrm{NOP}^{+/+}\right)$. As reported previously (Marti et al., 2004), $\mathrm{NOP}^{-/-}$mice showed greater stepping activity than $\mathrm{NOP}^{+/+}$mice (Table 1). SNC-80 dose dependently improved stepping activity in both $\mathrm{NOP}^{+/+}$and $N O P^{-/-}$mice, being equally effective in both genotypes but more potent in $\mathrm{NOP}^{-1-}$ mice. Indeed, in $\mathrm{NOP}^{+/+}$mice, SNC-80 was ineffective at 0.01 and $1 \mathrm{mg} / \mathrm{kg}$, but caused a $\sim 32 \%$ and $\sim 40 \%$ increase in stepping at 1 and $3 \mathrm{mg} / \mathrm{kg}$, respectively. Meanwhile, in $\mathrm{NOP}^{-1-}$ mice, SNC-80 was effective in as little as $0.01 \mathrm{mg} / \mathrm{kg}$ and was maximally efficacious ( $\sim 39 \%)$ at $0.1 \mathrm{mg} / \mathrm{kg}$, demonstrating a leftward shift of the effective dose in this genotype.

\section{Discussion}

DOP transmission has long been investigated as a target in PD. Indeed, the levels of enkephalins (the endogenous ligands of the DOP receptor) along the striato-pallidal pathway rise after striatal DA denervation (Goto et al., 1990; Betarbet and Greenamyre, 2004), possibly to relieve pallidofugal neurons from excessive GABAergic inhibition, and rescue motor function (Maneuf et al., 1994). Consistently, DOP receptor agonists provide symptomatic relief in parkinsonian rats (Matsumoto et al., 1988; Pinna and Di Chiara, 1998; Hill et al., 2000; Hudzik et al., 2000; Hille et al., 2001; Mabrouk et al., 2008, 2009) and nonhuman primates (Hille et al., 2001). However, different from endogenous transmitters, DOP agonists given systemically do not act on pallidal receptors but rather on SNr DOP receptors, likely because pallidal DOP receptors are saturated by endogenous enkephalins (Mabrouk et al., 2008, 2009). However, the therapeutic antiparkinsonian potential of small-molecule DOP agonists is somewhat limited by adverse effects occurring at high doses, in particular convulsions.

The present finding that blockade of the NOP receptor synergistically potentiates the antiparkinsonian effect of SNC-80 offers a strategy to circumvent this issue. The synergism between J-113397 and SNC-80 reveals that endogenous N/OFQ via the NOP receptor functionally opposes the positive influence of DOP transmission on movement, a modulation that may even be enhanced under parkinsonian conditions when brain N/OFQ levels are pathologically elevated (Marti et al., 2005, 2012).

A negative interaction between endogenous N/OFQ and classical opioid systems has been observed in pain circuitry and attributed to the different localizations of NOP and classical (in particular MOP) receptors in rostroventral medulla "on" and "off" neurons (Heinricher et al., 1997; Pan et al., 2000). The present study does not identify the precise localization of the interacting receptors, although it unequivocally demonstrates that the negative interaction between endogenous N/OFQ and
DOP transmission occurs in $\mathrm{SNr}$, in which both NOP and DOP receptor binding can be found (Neal et al., 1999; Cahill et al., 2001). In addition, it mechanistically indicates that this interaction ultimately controls nigro-thalamic GABA output neurons. Indeed, in vivo neurochemical and behavioral data reveal that NOP receptor blockade and DOP receptor stimulation in $\mathrm{SNr}$ attenuate akinesia, simultaneously elevate nigral GABA, and inhibit both nigral Glu and thalamic GABA. This is consistent with the view that enhancing inhibitory GABA and reducing excitatory Glu inputs onto tonically active nigro-thalamic neurons leads to overinhibition of nigral output, resulting in thalamic disinhibition and motor activation (Deniau and Chevalier, 1985). These data are substantially confirmed by electrophysiology in nigral slices in which combined application of an NOP antagonist and a DOP agonist evoked postsynaptic IPSPs in GABA neurons through presynaptic mechanisms (i.e., increased GABA release).

The mechanisms underlying the interaction between endogenous $\mathrm{N} / \mathrm{OFQ}$ and DOP receptors remain a matter for speculation. The increase of SNC-80 potency in stimulating stepping activity observed in $\mathrm{NOP}^{-/-}$mice suggests that NOP receptor blockade might increase the binding affinity of the DOP receptor. Indeed, compensatory, area-dependent changes in DOP receptor autoradiographic binding were observed in N/OFQ knock-out mice, such as a $+18 \%$ increase in SN (Clarke et al., 2003). However, this finding was not replicated in NOP receptor knock-out mice (Clarke et al., 2001) or rats (Homberg et al., 2009), favoring the view that endogenous $\mathrm{N} / \mathrm{OFQ}$ might rather functionally interact with DOP signaling at the cellular level or even at the circuitry level.

The synergism between J-113397 and SNC-80 suggests that inhibitory NOP and excitatory DOP receptors coexist on nigral afferent GABAergic terminals. Indeed, although DOP and NOP receptors are thought to transduce inhibitory signals into the cell because they couple to $G_{i}$, DOP receptors can also activate excitatory pathways and increase $\left[\mathrm{Ca}_{\mathrm{i}}\right]$, possibly through the $\beta \gamma$ subunit complex (Charles and Hales, 2004). However, because we observed inhibition of GABA release at higher SNC-80 doses (3 $\mathrm{mg} / \mathrm{kg}$; Mabrouk et al., 2008), it is likely that presynaptic DOP receptors on nigral GABA terminals are inhibitory, in line with that found in other brain areas (Ma et al., 2006). Therefore, the facilitatory effect of low SNC-80 doses might be related to disinhibiton, i.e., to the activation of DOP receptors on neuronal elements (e.g., GABA interneurons), that in turn inhibit GABA 
release presynaptically. This hypothesis relies on the evidence of somatodendritic DOP receptor labeling in $\mathrm{SNr}$ (Cahill et al., 2001). The synergistic increase of GABA release might thus be achieved via simultaneous blockade of a direct presynaptic inhibitory tone (NOP receptor) and inhibition of local inhibitory pathways (DOP receptor). Alternatively, because both J-113397 and SNC-80 share the same neurochemical pattern, we cannot exclude the possibility that the synergism is attributable to crosstalk between NOP and DOP receptors expressed on the membrane of a common substrate, perhaps GABA interneurons, inhibiting GABA terminals.

Whatever the molecular mechanism, the synergism seems to be effective across different PD models because it was also observed in MPTP-treated mice. Although this model is not routinely used to assess the symptomatic effects of antiparkinsonian drugs, we and others (for review, see Sedelis et al., 2001) identified a mild but reproducible parkinsonian phenotype that is associated with $60 \%$ loss of TH-positive terminals in striatum and is reversed by L-DOPA, dopaminomimetics, and also NOP receptor antagonists (Viaro et al., 2008, 2010). The symptomatic effect of DOP agonists has been observed in rats and nonhuman primates. Here, we provide the first evidence that DOP receptor stimulation also reverses motor deficits in MPTP-treated mice.

SNC-80 rapidly internalizes the DOP receptor and induces tolerance over repeated treatment, as also demonstrated by the dramatic reduction of the motor stimulating effect of a low dose of SNC-80 after a second injection $24 \mathrm{~h}$ later (Jutkiewicz et al., 2005). Rapid (within $3 \mathrm{~d}$ ) development of tolerance was also observed after repeated administration of J-113397 in reserpinized mice (Volta et al., 2010) and NiK-21273 [2-[3-[4(2-Chloro-6-fluoro-phenyl)-piperidin-1-ylmethyl]-2-(morpholine-4carbonyl)-indol-1-yl]-acetamide] in 6-OHDA hemilesioned rats (Marti et al., 2013), although this phenomenon was not shared by another NOP receptor antagonist, SB-612111 [(-)-cis-1-methyl-7-[[4(2,6-dichlorophenyl)piperidin-1-yl]methyl]-6,7,8,9-tetrahydro-5Hbenzocyclohepten-5-ol], suggesting that this is not a class feature (Marti et al., 2013). Therefore, although $6 \mathrm{~d}$ may not be a long enough timeframe for assessing tolerance development, the finding that repeated coadministration of subthreshold doses of J-113397 and SNC-80 in MPTP-treated mice maintained its symptomatic effects over time suggests that this strategy may prevent the induction of tolerance over long-term therapy. It is noteworthy that improvement of motor activity was not associated with a significant sparing of TH-positive striatal terminals, suggesting that the effect was symptomatic. Nonetheless, because DOP receptor stimulation provided some degree of neuroprotection in 6-OHDA rats (Borlongan et al., 2000) and NOP receptor blockade is expected to be neuroprotective (genetic removal of the N/OFQ gene partially protected mice from MPTP-induced DA cell loss; Marti et al., 2005), it is possible that higher doses and/or more prolonged receptor occupation might be necessary to counteract MPTP-induced toxicity.

\section{Concluding remarks}

Endogenous N/OFQ functionally opposes DOP transmission in $\mathrm{SNr}$, as pointed out by the synergism between the NOP receptor antagonist J-113397 and the DOP receptor agonist SNC-80 in attenuating parkinsonian-like motor deficits in 6-OHDA hemilesioned rats and MPTP-treated mice. Although the neuronal location of the interacting receptors or the underlying molecular mechanism remains to be identified, the interaction between NOP and DOP receptors appears to be a powerful mechanism to regulate (overinhibit) nigro-thalamic neurons and promote movement. The synergism was confirmed in nigral slices of naive animals and in mice lacking the NOP receptor, suggesting that the interaction also occurs in the presence of an intact DA system. This might extend the potential of the synergism to the modulation of motor function under physiological conditions. Interestingly, because NOP receptor antagonists and DOP receptor agonists share not only the antiparkinsonian but also anxiolytic and antidepressant effects, the present study indicates that blockade of the NOP receptor might also be explored as a general mechanism to enhance the therapeutic effects of DOP receptor agonists and reduce their side effects in motor and nonmotor (e.g., mood) disorders.

\section{References}

Beaudry H, Proteau-Gagné A, Li S, Dory Y, Chavkin C, Gendron L (2009) Differential noxious and motor tolerance of chronic delta opioid receptor agonists in rodents. Neuroscience 161:381-391. CrossRef Medline

Berretta N, Bernardi G, Mercuri NB (2000) Alpha(1)-adrenoceptormediated excitation of substantia nigra pars reticulata neurons. Neuroscience 98:599-604. CrossRef Medline

Betarbet R, Greenamyre JT (2004) Regulation of dopamine receptor and neuropeptide expression in the basal ganglia of monkeys treated with MPTP. Exp Neurol 189:393-403. CrossRef Medline

Borlongan CV, Su TP, Wang Y (2000) Treatment with delta opioid peptide enhances in vitro and in vivo survival of rat dopaminergic neurons. Neuroreport 11:923-926. CrossRef Medline

Cahill CM, McClellan KA, Morinville A, Hoffert C, Hubatsch D, O’Donnell D, Beaudet A (2001) Immunohistochemical distribution of delta opioid receptors in the rat central nervous system: evidence for somatodendritic labeling and antigen-specific cellular compartmentalization. J Comp Neurol 440:65-84. CrossRef Medline

Calo G, Guerrini R, Rizzi A, Salvadori S, Burmeister M, Kapusta DR, Lambert DG, Regoli D (2005) UFP-101, a peptide antagonist selective for the nociceptin/orphanin FQ receptor. CNS Drug Rev 11:97-112. Medline

Charles AC, Hales TG (2004) From inhibition to excitation: functional effects of interaction between opioid receptors. Life Sci 76:479-485. CrossRef Medline

Chu Sin Chung P, Kieffer BL (2013) Delta opioid receptors in brain function and diseases. Pharmacol Ther 140:112-120. CrossRef Medline

Clarke S, Chen Z, Hsu MS, Pintar J, Hill R, Kitchen I (2001) Quantitative autoradiographic mapping of the ORL1, mu-, delta- and kappa-receptors in the brains of knockout mice lacking the ORL1 receptor gene. Brain Res 906:13-24. CrossRef Medline

Clarke S, Chen Z, Hsu MS, Hill RG, Pintar JE, Kitchen I (2003) Nociceptin/ orphanin FQ knockout mice display up-regulation of the opioid receptorlike 1 receptor and alterations in opioid receptor expression in the brain. Neuroscience 117:157-168. CrossRef Medline

Comer SD, Hoenicke EM, Sable AI, McNutt RW, Chang KJ, De Costa BR, Mosberg HI, Woods JH (1993) Convulsive effects of systemic administration of the delta opioid agonist BW373U86 in mice. J Pharmacol Exp Ther 267:888-895. Medline

Deniau JM, Chevalier G (1985) Disinhibition as a basic process in the expression of striatal functions. II. The striato-nigral influence on thalamocortical cells of the ventromedial thalamic nucleus. Brain Res 334:227-233. CrossRef Medline

Goto S, Hirano A, Matsumoto S (1990) Met-enkephalin immunoreactivity in the basal ganglia in Parkinson's disease and striatonigral degeneration. Neurology 40:1051-1056. CrossRef Medline

Heinricher MM, McGaraughty S, Grandy DK (1997) Circuitry underlying antiopioid actions of orphanin FQ in the rostral ventromedial medulla. J Neurophysiol 78:3351-3358. Medline

Hill MP, Hille CJ, Brotchie JM (2000) Delta-opioid receptor agonists as a therapeutic approach in Parkinson's disease. Drug News Perspect 13:261268. Medline

Hille CJ, Fox SH, Maneuf YP, Crossman AR, Brotchie JM (2001) Antiparkinsonian action of a delta opioid agonist in rodent and primate models of Parkinson's disease. Exp Neurol 172:189-198. CrossRef Medline

Homberg JR, Mul JD, de Wit E, Cuppen E (2009) Complete knockout of the nociceptin/orphanin FQ receptor in the rat does not induce compensatory changes in mu, delta and kappa opioid receptors. Neuroscience 163 : 308-315. CrossRef Medline

Hu E, Calò G, Guerrini R, Ko MC (2010) Long-lasting antinociceptive spi- 
nal effects in primates of the novel nociceptin/orphanin FQ receptor agonist UFP-112. Pain 148:107-113. CrossRef Medline

Hudzik TJ, Howell A, Payza K, Cross AJ (2000) Antiparkinson potential of delta-opioid receptor agonists. Eur J Pharmacol 396:101-107. CrossRef Medline

Jutkiewicz EM, Kaminsky ST, Rice KC, Traynor JR, Woods JH (2005) Differential behavioral tolerance to the delta-opioid agonist SNC80 $([(+)-4-$ [(alphaR)-alpha-[(2S,5R)-2,5-dimethyl-4-(2-propenyl)-1-piperazinyl](3-me thoxyphenyl)methyl]-N, N-diethylbenzamide) in Sprague-Dawley rats. J Pharmacol Exp Ther 315:414-422. CrossRef Medline

Jutkiewicz EM, Baladi MG, Folk JE, Rice KC, Woods JH (2006) The convulsive and electroencephalographic changes produced by nonpeptidic delta-opioid agonists in rats: comparison with pentylenetetrazol. J Pharmacol Exp Ther 317:1337-1348. CrossRef Medline

Ko MC, Naughton NN (2009) Antinociceptive effects of nociceptin/orphanin FQ administered intrathecally in monkeys. J Pain 10:509-516. CrossRef Medline

Kuschinsky K, Hornykiewicz O (1972) Morphine catalepsy in the rat: relation to striatal dopamine metabolism. Eur J Pharmacol 19:119-122. CrossRef Medline

Lutfy K, Eitan S, Bryant CD, Yang YC, Saliminejad N, Walwyn W, Kieffer BL, Takeshima H, Carroll FI, Maidment NT, Evans CJ (2003) Buprenorphine-induced antinociception is mediated by mu-opioid receptors and compromised by concomitant activation of opioid receptorlike receptors. J Neurosci 23:10331-10337. Medline

Ma J, Zhang Y, Kalyuzhny AE, Pan ZZ (2006) Emergence of functional delta-opioid receptors induced by long-term treatment with morphine. Mol Pharmacol 69:1137-1145. CrossRef Medline

Mabrouk OS, Volta M, Marti M, Morari M (2008) Stimulation of delta opioid receptors located in substantia nigra reticulata but not globus pallidus or striatum restores motor activity in 6-hydroxydopamine lesioned rats: new insights into the role of delta receptors in parkinsonism. J Neurochem 107:1647-1659. CrossRef Medline

Mabrouk OS, Marti M, Salvadori S, Morari M (2009) The novel delta opioid receptor agonist UFP-512 dually modulates motor activity in hemiparkinsonian rats via control of the nigro-thalamic pathway. Neuroscience 164:360-369. CrossRef Medline

Maneuf YP, Mitchell IJ, Crossman AR, Brotchie JM (1994) On the role of enkephalin cotransmission in the GABAergic striatal efferents to the globus pallidus. Exp Neurol 125:65-71. CrossRef Medline

Marti M, Mela F, Bianchi C, Beani L, Morari M (2002) Striatal dopamineNMDA receptor interactions in the modulation of glutamate release in the substantia nigra pars reticulata in vivo: opposite role for D1 and D2 receptors. J Neurochem 83:635-644. CrossRef Medline

Marti M, Mela F, Veronesi C, Guerrini R, Salvadori S, Federici M, Mercuri NB, Rizzi A, Franchi G, Beani L, Bianchi C, Morari M (2004) Blockade of nociceptin/orphanin FQ receptor signaling in rat substantia nigra pars reticulata stimulates nigrostriatal dopaminergic transmission and motor behavior. J Neurosci 24:6659-6666. CrossRef Medline

Marti M, Mela F, Fantin M, Zucchini S, Brown JM, Witta J, Di Benedetto M, Buzas B, Reinscheid RK, Salvadori S, Guerrini R, Romualdi P, Candeletti S, Simonato M, Cox BM, Morari M (2005) Blockade of nociceptin/orphanin FQ transmission attenuates symptoms and neurodegeneration associated with Parkinson's disease. J Neurosci 25:9591-9601. CrossRef Medline

Marti M, Trapella C, Viaro R, Morari M (2007) The nociceptin/orphanin FQ receptor antagonist J-113397 and L-DOPA additively attenuate experimental parkinsonism through overinhibition of the nigrothalamic pathway. J Neurosci 27:1297-1307. CrossRef Medline

Marti M, Trapella C, Morari M (2008) The novel nociceptin/orphanin FQ receptor antagonist Trap-101 alleviates experimental parkinsonism through inhibition of the nigro-thalamic pathway: positive interaction with L-DOPA. J Neurochem 107:1683-1696. CrossRef Medline

Marti M, Rodi D, Li Q, Guerrini R, Fasano S, Morella I, Tozzi A, Brambilla R, Calabresi P, Simonato M, Bezard E, Morari M (2012) Nociceptin/orphanin FQ receptor agonists attenuate L-DOPA-induced dyskinesias. J Neurosci 32:16106-16119. CrossRef Medline

Marti M, Mela F, Budri M, Volta M, Malfacini D, Molinari S, Zaveri NT, Ronzoni S, Petrillo P, Calò G, Morari M (2013) Acute and chronic antiparkinsonian effects of the novel nociceptin/orphanin FQ receptor antagonist NiK-21273 in comparison with SB-612111. Br J Pharmacol 168: 863-879. CrossRef Medline
Matsumoto RR, Brinsfield KH, Patrick RL, Walker JM (1988) Rotational behavior mediated by dopaminergic and nondopaminergic mechanisms after intranigral microinjection of specific mu, delta and kappa opioid agonists. J Pharmacol Exp Ther 246:196-203. Medline

Neal CR Jr, Mansour A, Reinscheid R, Nothacker HP, Civelli O, Akil H, Watson SJ Jr (1999) Opioid receptor-like (ORL1) receptor distribution in the rat central nervous system: comparison of ORL1 receptor mRNA expression with (125)I-[(14)Tyr]-orphanin FQ binding. J Comp Neurol 412:563-605. CrossRef Medline

Negus SS, Butelman ER, Chang KJ, DeCosta B, Winger G, Woods JH (1994) Behavioral effects of the systemically active delta opioid agonist BW373U86 in rhesus monkeys. J Pharmacol Exp Ther 270:1025-1034. Medline

Nishi M, Houtani T, Noda Y, Mamiya T, Sato K, Doi T, Kuno J, Takeshima H, Nukada T, Nabeshima T, Yamashita T, Noda T, Sugimoto T (1997) Unrestrained nociceptive response and disregulation of hearing ability in mice lacking the nociceptin/orphaninFQ receptor. EMBO J 16:18581864. CrossRef Medline

Pan Z, Hirakawa N, Fields HL (2000) A cellular mechanism for the bidirectional pain-modulating actions of orphanin FQ/nociceptin. Neuron 26: 515-522. CrossRef Medline

Paxinos G, Watson C (1986) The rat brain in stereotaxic coordinates, Ed 2. Sydney: Academic.

Pinna A, Di Chiara G (1998) Dopamine-dependent behavioural stimulation by non-peptide delta opioids BW 373 U86 and SNC 80: 3. Facilitation of D1 and D2 responses in unilaterally 6-hydroxydopamine-lesioned rats. Behav Pharmacol 9:15-21. Medline

Pradhan AA, Befort K, Nozaki C, Gavériaux-Ruff C, Kieffer BL (2011) The delta opioid receptor: an evolving target for the treatment of brain disorders. Trends Pharmacol Sci 32:581-590. CrossRef Medline

Rozas G, Guerra MJ, Labandeira-García JL (1997) An automated rotarod method for quantitative drug-free evaluation of overall motor deficits in rat models of parkinsonism. Brain Res Brain Res Protoc 2:75-84. CrossRef Medline

Schallert T, De Ryck M, Whishaw IQ, Ramirez VD, Teitelbaum P (1979) Excessive bracing reactions and their control by atropine and L-DOPA in an animal analog of Parkinsonism. Exp Neurol 64:33-43. CrossRef Medline

Sedelis M, Schwarting RK, Huston JP (2001) Behavioral phenotyping of the MPTP mouse model of Parkinson's disease. Behav Brain Res 125:109_ 125. CrossRef Medline

Smith AP, Lee NM (2003) Opioid receptor interactions: local and nonlocal, symmetric and asymmetric, physical and functional. Life Sci 73:18731893. CrossRef Medline

Stevenson GW, Folk JE, Linsenmayer DC, Rice KC, Negus SS (2003) Opioid interactions in rhesus monkeys: effects of delta + mu and delta + kappa agonists on schedule-controlled responding and thermal nociception. J Pharmacol Exp Ther 307:1054-1064. CrossRef Medline

Stevenson GW, Folk JE, Rice KC, Negus SS (2005) Interactions between delta and mu opioid agonists in assays of schedule-controlled responding, thermal nociception, drug self-administration, and drug versus food choice in rhesus monkeys: studies with SNC80 [(+)-4-[(alphaR)-alpha-((2S,5R)-4-allyl-2,5dimethyl-1-piperazinyl)-3-methoxybenz yl]-N, N-diethylbenzamide] and heroin J Pharmacol Exp Ther 314:221-231. CrossRef

Tian JH, Xu W, Fang Y, Mogil JS, Grisel JE, Grandy DK, Han JS (1997) Bidirectional modulatory effect of orphanin FQ on morphine-induced analgesia: antagonism in brain and potentiation in spinal cord of the rat. Br J Pharmacol 120:676-680. CrossRef Medline

Viaro R, Sanchez-Pernaute R, Marti M, Trapella C, Isacson O, Morari M (2008) Nociceptin/orphanin FQ receptor blockade attenuates MPTPinduced parkinsonism. Neurobiol Dis 30:430-438. CrossRef Medline

Viaro R, Marti M, Morari M (2010) Dual motor response to l-dopa and nociceptin/orphanin FQ receptor antagonists in 1-methyl-4-phenyl1,2,5,6-tetrahydropyridine (MPTP) treated mice: Paradoxical inhibition is relieved by $D(2) / D(3)$ receptor blockade. Exp Neurol 223:473-484. CrossRef Medline

Volta M, Mabrouk OS, Bido S, Marti M, Morari M (2010) Further evidence for an involvement of nociceptin/orphanin FQ in the pathophysiology of Parkinson's disease: a behavioral and neurochemical study in reserpinized mice. J Neurochem 115:1543-1555. CrossRef Medline

Zhang Z, Pan ZZ (2010) Synaptic mechanism for functional synergism between delta- and mu-opioid receptors. J Neurosci 30:4735-4745. CrossRef Medline 